\section{'Cowichan' Red Raspberry}

\section{Chaim Kempler, ${ }^{1}$ Hugh A. Daubeny, ${ }^{2}$ Brian Harding, and C. Grant Kowalenko \\ Agriculture and Agri-Food Canada, Pacific Agri-Food Research Centre, P.O. Box 1000, Agassiz, B.C., Canada V0M 1 AO}

Additional index words. Rubus idaeus, fruit breeding, fruit quality, yield, machine harvesting, disease resistance

'Cowichan'(Fig. 1) is a new floricane-fruiting red raspberry (Rubus idaeus L.) cultivar from the breeding program at the Pacific AgriFood Research Centre (PARC) of Agriculture and Agri-Food Canada(AAFC), Agassiz, B.C. 'Cowichan' produces high yields of large, relatively firm fruit suited to machine harvest. It is adapted to both the processing and fresh markets. It appears to escape infection from the pollen-borne raspberry bushy dwarf virus (RBDV) and might be resistant or immune. It is resistant to the common strain of the North American aphid vector, Amphorophora agathonica Hottes, of the raspberry mosaic virus (RMV) complex. 'Cowichan' is the name of a lake on Vancouver Island and follows the tradition of naming PARC berry cultivars with B.C. First Nations names. 'Cowichan' translates as warmed by the sun or warm country.

\section{Origin}

'Cowichan', which was tested as BC 8714-20, was selected by H.A. Daubeny from a 1987 cross of 'Newburgh' × 'Qualicum' (Fig. 2). 'Newburgh', released from Geneva, N.Y. in 1929, was chosen as a parent because of its resistance to root rot, caused by Phytophthora fragariae var. rubi Wilcox \& Duncan, and also its resistance or possible immunity to RBDV (Daubeny et al., 1978; Levesque and Daubeny, 1999). 'Qualicum'was released from the PARC program in 1995 and was chosen as a parent because of its high yield, good fruit quality and resistance to aphids (Daubeny and Kempler 1995). The origin of 'Cowichan' demonstrates the value of combining the high yield and high quality traits of a modern-day raspberry cultivar with the disease resistance traits of an old cultivar. Moreover, 'Qualicum' is largely derived from germplasm that was developed

Received for publication 19 Apr. 2005. Accepted for publication 17 May 2005. This research was partially funded by the Raspberry Industry Development Council, Lower Mainland Horticultural Improvement Association and the Washington Red Raspberry Commission. We gratefully acknowledge the assistance of M. Gross and M. Bodnar, of the Pacific Agri-Food Research Centre; M. Sweeney, British Columbia Ministry of Agriculture Food and Fisheries; T. Baumann, University College of the Fraser Valley; P. Moore, Washington State University (WSU), Puyallup; C. Finn and R. Martin, U.S. Department of Agriculture, Corvallis, Ore. Pacific Agri-Food Research Centre (PARC), Agassiz contribution no. 723 .

${ }^{1}$ To whom correspondence should be addressed: e-mailkemplerc@agr.gc.ca.

${ }^{2}$ Emeritus research scientist. in the United Kingdom and contains Rubus occidentalis L. in its ancestry, and 'Newburgh' originates from germplasm developed in North America (Fig. 2). This might be another maxim for selecting parents in present day breeding programs.

\section{Performance and Description}

Performance data for 'Cowichan' and several other Pacific Northwest (PNW) cultivars, including the widely planted 'Meeker', were obtained from four replicated plantings set in 1996, 1999, 2000, and 2001 at PARC's substation in Abbotsford, B.C. (Tables 1 and 2). The first three plantings were evaluated for 3 years, while the last one was evaluated for 2 years. Each planting was arranged in a randomized complete-block design in which each cultivar

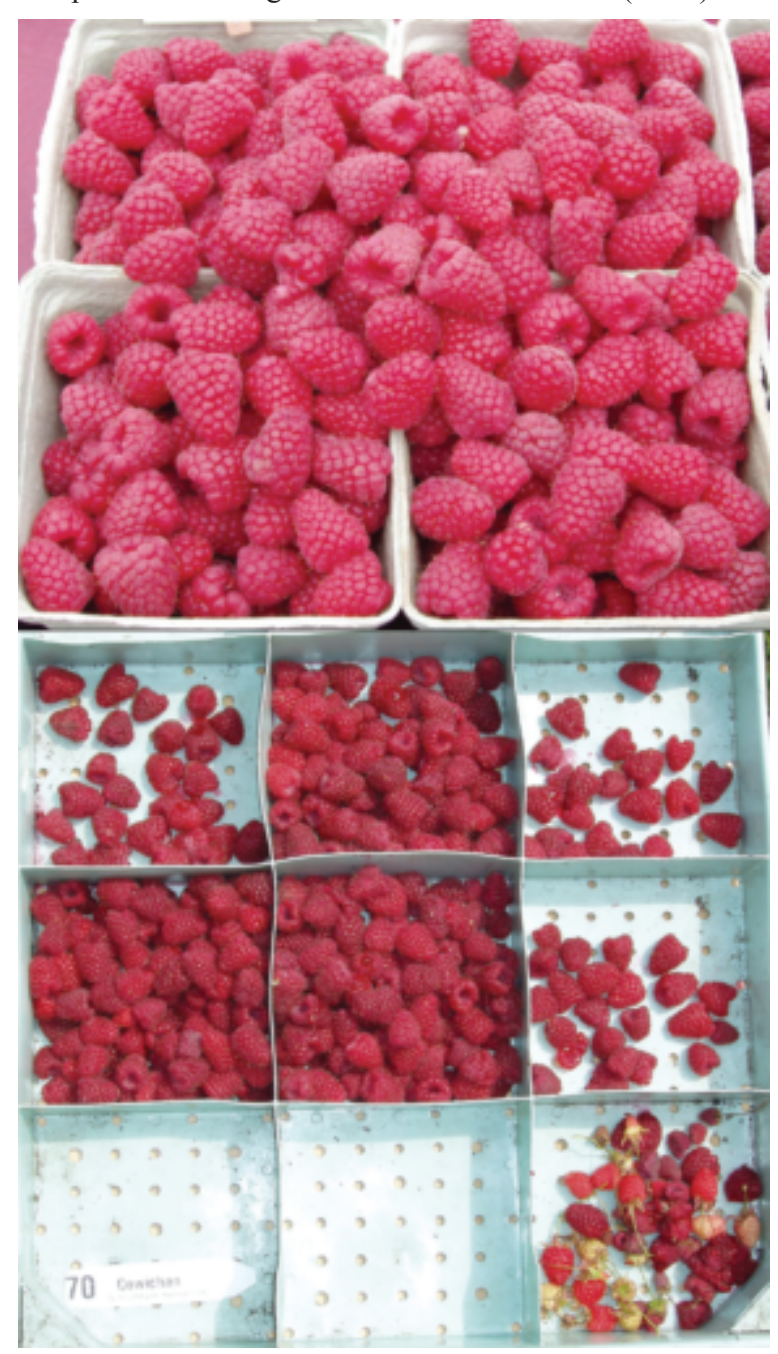

was represented by three 3-plant replications with $0.9 \mathrm{~m}$ between plants and $3 \mathrm{~m}$ between rows. Yield, fruit weight, fruit firmness, dates of harvest and postharvest fruit rot (caused primarily by Botrytis cinerea Pers. ex. Fr.) were measured each season from 1999 to 2004. Soluble solids concentration (SSC), firmness, titratable acidity and postharvest fruit rot tests were determined according to Barritt et al. (1980) and Daubeny and Pepin (1974). Ripe berries were harvested from 9 to 14 times a season, depending on the length of a cultivar's harvest period and environmental conditions. The average fruit weight for the season is a weighted mean, calculated from the weight of a randomly selected 50-fruit subsample from each plot on each harvest and adjusted according to the yield for each harvest. The fruit ripening season was characterized by the dates at which $5 \%, 50 \%$, and $95 \%$ were reached (Table 2 ). Fruit firmness was measured as the force required to close the opening of freshly picked ripe berries with a push-pull spring gauge (Hunter Spring Mechanical Force Gauge Series L; Ametek, Hatfield, $\mathrm{Pa}$.) and was calculated on a subsample of ten randomly selected fruit, three to five times each harvest season. Fruit samples were frozen until determination of $\mathrm{pH}$ and titratable acidity (as a percentage of citric acid) on a thawed subsample. 'Cowichan' was also evaluated in Washington state [Washington State University (WSU)-Mt. Vernon, and WSU-Puyallup], at the Oregon State University-North Willamette Research and Extension Center in Aurora, Oregon (OSU-NWREC in Aurora) and in British Columbia, Washington, and Oregon grower fields.

Yield was the only variable in which there was a significant interaction of cultivar $\times$ planting year $(p=0.001)$ and cultivar $\times$ harvest year $(p=0.03)$ and hence data are presented for each planting year (Table 1). For the other variables, means of all harvest years are presented for each cultivar (Tables 2 and 3). 'Cowichan' produced significantly higheryields than 'Meeker' in six planting $\times$ harvest year combinations, lower than 'Meeker' in two and not significantly different in three (Table 1). 'Cowichan' yield was significantly higher than yields of 'Qualicum' in two planting $\times$ harvest year combinations, lower in six, and not significantly different in three (Table 1). This indicates that 'Cowichan' yielded more than the standard 'Meeker' but less than its parent 'Qualicum'.

Fig. 1. (a) 'Cowichan' red raspberry fruit hand harvested from PARC's substation in Abbotsford, B.C. (b) 'Cowichan' fruit from a machine harvest trial in Lynden, Wash.; lower right compartment contains green and overripe fruit. 


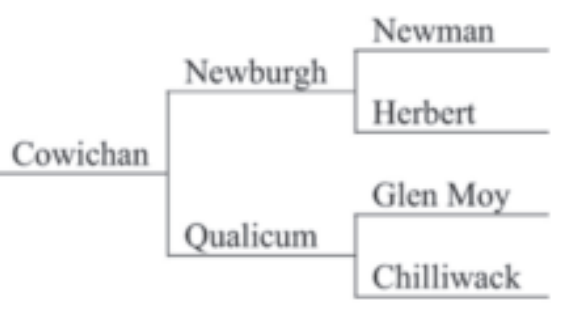

Fig. 2. Pedigree of 'Cowichan'.

'Qualicum' is recognized as high yielding cultivar (Daubeny and Kempler, 1995).

'Cowichan' fruit size was significantly larger than that of 'Meeker' and not different from that of the other cultivars (Table 1).

The harvest season of 'Cowichan' can be characterized as a few days earlier than 'Meeker', 'Qualicum', and 'Tulameen' but later than 'Malahat', which is recognized for its earliness (Kempler and Daubeny, 2000) (Table 2). 'Cowichan' harvest duration was similar to that of 'Malahat' and 'Qualicum', longer than 'Meeker' and shorter than 'Tulameen'.

'Cowichan' fruit are long and conical, and are medium red in color. Fruit are clear and shiny, not dull like its parent 'Qualicum', giving 'Cowichan' fruit an excellent overall appearance. 'Cowichan' soluble solids concentration was the lowest of all cultivars tested, however this difference was significant only in comparison with 'Qualicum' and 'Tulameen'. 'Cowichan' fruit firmness was significantly higher than that of 'Meeker' and not significantly different from that of the other cultivars (Table 3). Percent postharvest fruit rot of 'Cowichan' was similar to 'Meeker', lower than of that of 'Tulameen', and higher of that of 'Qualicum' and 'Malahat' (Table 3), which are known for their good postharvest fruit quality (Daubeny and Kempler, 1995; Kempler and Daubeny, 2000). Titratable acidity and $\mathrm{pH}$ of 'Cowichan' are very similar to that of 'Meeker' (Table 3), which suggests that it is acceptable for processing.

In replicated machine harvesting trials planted in 2001 at the WSU-Vancouver, 'Cowichan' produced the highest yield and had the highest rated fruit quality (unpublished). In genotype trials at the OSU-NWREC in Aurora, 'Cowichan' yield was average and was not significantly different from 'Qualicum', 'Meeker', and 'Willamette'. Mean fruit size of machine harvest samples of 'Cowichan' was $4.4 \mathrm{~g}$, compared to $3.6 \mathrm{~g}$ for 'Meeker',
$3.7 \mathrm{~g}$ for 'Willamette' (once the most widely planted cultivar throughout the PNW), $4.8 \mathrm{~g}$ for 'Tulameen', and $5.0 \mathrm{~g}$ for 'Qualicum'. In this trial, fruit was rated as very good when hand harvested for fresh market under conditions of extreme heat (unpublished data).

'Cowichan'flowers are self fertile, and percentage of drupelets set under field conditions appears to be similar to that of 'Qualicum', 'Malahat', and 'Meeker', each of which is recognized for high percentage of set (Daubeny, 1971; Daubeny and Kempler, 1995; Kempler and Daubeny, 2000).

'Cowichan' was observed to be a vigorous growing cultivar with a strong upright habit and canes significantly thicker than those of 'Meeker', 'Malahat', and 'Tulameen'. 'Cowichan' internodes are long, therefore it has fewer buds per cane. However, it has a higher number of fruiting laterals and therefore a higher percentage of bud break (Table 4). 'Cowichan' canes bear long, strong, upwardgrowing laterals, allowing fruit to be well spaced. These observations were supported by winter of 2005 measurements of canes in the 2000 planting (Table 4). 'Cowichan' is a vigorous variety, producing more primocanes per hill than 'Meeker', 'Tulameen', or 'Qualicum'. 'Cowichan' floricanes are light brown with some reddish and grey parts. Cracks are present in the lower $1 \mathrm{~m}$ of the canes; under the cracked bark, canes are dark brown. Spines are present in the lower $40 \mathrm{~cm}$ but there are very few spines on top. Spines are light grey in color.

In large-scale grower trials in British Columbia and Washington state, 'Cowichan' has shown itself very suited for mechanical harvesting, producing a crop that is not overripe and is free of green fruit. Fruit color is acceptable for processing and is comparable to that of 'Meeker', which is the main processing cultivar grown in the PNW. The cultivar is very quick to establish and produces high yields after the first planting year (personal communication)

'Cowichan' has been characterized by simple sequence repeat (SSR) marker analysis for three markers; the patterns obtained were group 4, 4, and 5 for the first, second, and third markers, respectively (Graham et al., 2002).

\section{Disease and Pest Reaction}

'Cowichan' was selected in greenhouse screening trails for resistance conferred by the gene $\mathrm{Ag}_{1}$ to the common biotype of $\mathrm{Am}$ phorophora agathonica Hottes, the North American aphid vector of the raspberry mosaic virus (RMV) complex. Aphid colonization has been noted on plants of the cultivar in trials at the PARC Agassiz, Abbotsford substation. We assume that this is a resistance-breaking biotype of the aphid, which has been found on other cultivars with $\mathrm{Ag}_{1}$ gene (Kempler and Daubeny, 2000).

'Cowichan' has been indexed yearly (1994-2003) for RMV using the doublestranded RNA technique (Kurppa and Martin, 1986) and for RBDV using the enzyme-linked immunosorbent assay technique (ELISA). It has consistently tested negative. 'Cowichan' was planted within a large 'Meeker' planting along with other PNW cultivars and selections in Lynden, Wash. After 8 years, all the 'Meeker' plants tested positive while 'Cowichan' tested to be free of RBDV (unpublished data). 'Cowichan' appears to withstand the common RBDV strain present in the PNW and even under high pressure it has tested to be free of RBDV (data not presented). It is very likely that 'Cowichan' inherited its resistance to RBDV from 'Newburgh', which has never tested positive to RBDV in North America and therefore might be immune (Daubeny et al., 1978; unpublished data; personal communication). 'Cowichan' was not tested for its resistance to the RBDV resistance-breaking strain, a strain that is not present in North America.

Exposure to Phytophthora fragariae Hickman var. rubi Wilcox \& Duncan in greenhouse pot tests showed that 'Cowichan' was more resistant than its parent 'Qualicum' and less resistant than 'Newburgh' (Levesque and Daubeny, unpublished data). In field trials at the WSU Research and Extension Center at Puyallup, it was susceptible to root rot caused by Phytophthora fragariae Hickman var. rubi under extreme pressure. At the Mt. Vernon Research Station, it showed very vigorous growth and moderate susceptibility to root rot (unpublished data). In grower plantings in British Columbia, it appears that 'Cowichan' survives under root rot pressure better than 'Malahat', 'Meeker', 'Willamette', or 'Qualicum' (personal communication). It is possible that Cowichan is resistant to some races of Phytophthora fragariae Hickman var. rubi but not others.

In the PNW, 'Cowichan' has been moderately susceptible to spur blight [Didymella applanata (Niessl) Sacc.], has low susceptibility

Table 1. Yearly yield (kg/hill) and fruit weight of 'Cowichan' and other Pacific Northwest raspberry cultivars in four plantings.

\begin{tabular}{|c|c|c|c|c|c|c|c|c|c|c|c|c|}
\hline \multirow[b]{4}{*}{ Cultivar } & \multicolumn{11}{|c|}{ Planting year } & \multirow{4}{*}{$\begin{array}{l}\text { Fruit } \\
w^{2}(g)\end{array}$} \\
\hline & \multicolumn{3}{|c|}{1996} & \multicolumn{2}{|r|}{1999} & & \multicolumn{3}{|c|}{2000} & \multicolumn{2}{|c|}{2001} & \\
\hline & \multicolumn{11}{|c|}{ Harvest year } & \\
\hline & 1999 & 2000 & 2001 & 2001 & 2002 & 2003 & 2002 & 2003 & 2004 & 2003 & 2004 & \\
\hline Cowichan & 3.87 & 4.25 & 3.97 & 3.68 & 3.34 & 4.13 & 3.43 & 3.44 & 4.30 & 5.28 & 4.56 & $4.2 \mathrm{a}^{\mathrm{y}}$ \\
\hline Malahat & 5.02 & 3.68 & 4.02 & 4.99 & 2.89 & 3.83 & 3.89 & 4.17 & 3.65 & 3.29 & 4.84 & $4.2 \mathrm{a}$ \\
\hline Meeker & 4.07 & 3.67 & 3.07 & 4.23 & 3.14 & 4.24 & 2.63 & 4.02 & 3.66 & 3.22 & 3.74 & $3.0 \mathrm{~b}$ \\
\hline Qualicum & 4.35 & 4.44 & 4.61 & 7.18 & 4.19 & 5.42 & 4.47 & 3.17 & 3.05 & 5.54 & 3.39 & $4.3 \mathrm{a}$ \\
\hline Tulameen & 4.06 & 4.28 & 3.36 & 6.60 & 4.48 & --- & 3.87 & 4.11 & 4.12 & --- & 3.95 & $4.4 \mathrm{a}$ \\
\hline $\mathrm{LSD}^{\mathrm{x}}$ & & & & & & 0.37 & & & & & & \\
\hline
\end{tabular}

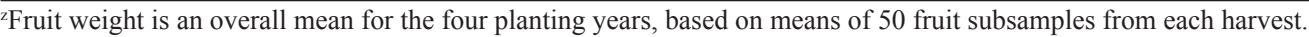

${ }^{y}$ Mean separation within the column by Student-Newman-Keuls multiple range test, $P=0.05$.

${ }^{x}$ Mean separation with least significant difference (LSD), $P=0.05$. 
Table 2. Harvest season for 'Cowichan' and other Pacific Northwest red raspberry cultivars.

\begin{tabular}{|c|c|c|c|c|}
\hline \multirow[b]{2}{*}{ Cultivar } & \multicolumn{3}{|c|}{ Harvest season } & \multirow{2}{*}{$\begin{array}{l}\text { Harvest } \\
\text { duration } \\
\text { (d) }\end{array}$} \\
\hline & Start (5\%) & Midpoint & $\overline{\text { End }(95 \%)}$ & \\
\hline Cowichan & 2 July $c^{z}$ & 14 July ab & 31 July b & $30 \mathrm{bc}$ \\
\hline Malahat & 29 June $d$ & 11 July b & 29 July b & $32 \mathrm{~b}$ \\
\hline Meeker & 4 July a & 17 July a & 31 July b & $28 \mathrm{~d}$ \\
\hline Qualicum & 3 July b & 18 July a & 1 Aug. b & $30 \mathrm{~cd}$ \\
\hline Tulameen & 4 July a & 17 July a & 7 Aug. a & $35 \mathrm{a}$ \\
\hline
\end{tabular}

${ }^{\mathrm{z}}$ Mean separation within columns by Student-Newman-Keuls multiple range test, $P=0.05$.

Table 3. Fruit traits of 'Cowichan' and other Pacific Northwest red raspberry cultivars.

\begin{tabular}{lccccc}
\hline & $\begin{array}{c}\text { Soluble } \\
\text { solids } \\
(\%)\end{array}$ & $\begin{array}{c}\text { Firmness } \\
(\mathrm{N})\end{array}$ & $\begin{array}{c}\text { Botrytis-incited } \\
\text { fruit rot after } \\
48 \mathrm{~h}(\%)\end{array}$ & $\mathrm{pH}$ & $\begin{array}{c}\text { Titratable } \\
\text { acidity } \\
\text { Cultivar }\end{array}$ \\
\hline Cowichan & $10.2 \mathrm{~b}^{\mathrm{z}}$ & $1.97 \mathrm{a}$ & $26.5 \mathrm{~b}$ & $2.97 \mathrm{a}$ & $1.00 \mathrm{ab}$ \\
Malahat & $10.8 \mathrm{ab}$ & $2.17 \mathrm{a}$ & $20.2 \mathrm{c}$ & $2.93 \mathrm{ab}$ & $0.97 \mathrm{~b}$ \\
Meeker & $10.7 \mathrm{ab}$ & $1.53 \mathrm{~b}$ & $25.9 \mathrm{~b}$ & $2.86 \mathrm{~b}$ & $0.95 \mathrm{~b}$ \\
Qualicum & $11.3 \mathrm{a}$ & $2.32 \mathrm{a}$ & $21.5 \mathrm{c}$ & $2.87 \mathrm{~b}$ & $1.14 \mathrm{a}$ \\
Tulameen & $11.1 \mathrm{a}$ & $2.20 \mathrm{a}$ & $31.3 \mathrm{a}$ & $2.82 \mathrm{~b}$ & $1.20 \mathrm{a}$ \\
\hline
\end{tabular}

${ }^{\mathrm{z}}$ Mean separation within columns by Student-Newman-Keuls multiple range test, $P=0.05$

to cane Botrytis (B. cinerea) and is much less susceptible to anthracnose (Elsinoe veneta Burkh.) than its parent 'Qualicum' (data not presented).

\section{Adaptability and Uses}

'Cowichan' is a multipurpose cultivar suited for both processing and fresh market uses in the PNW. It is suited for machine harvesting. It is suggested that the cultivar be considered as a replacement for 'Meeker', currently the most widely-planted red raspberry cultivar in the PNW. 'Meeker' is suitable for processing but has limitations for fresh market use and 'Meeker' is susceptible to the pollen-borne RBDV, with fields becoming 100\% infected within 5 to 6 years (Martin, 1998). Infected plants show poor fruit set and reduced yield (Daubeny et al., 1978). 'Cowichan' appears to resist pollen infection from RBDV and thus plantings would have to be replaced much less frequently than those of 'Meeker'. In addition, 'Cowichan' may have more resistance or tolerance than 'Meeker' to Phytophthora forasariae var. rubi, the main organism to cause root rot of raspberries in the PNW.

\section{Availability}

Certified 'Cowichan' plants are being propagated under royalty agreements with propagators in the PNW. For licensing information contact Okanagan Plant Improve- ment Company (PICO), P.O. Box 6000, Summerland, BC, V0H 1Z0, Canada, e-mail PICO@agr.gc.ca

\section{Literature Cited}

Barritt, B.H., L.C. Torre, H.S. Pepin, and H.A. Daubeny. 1980. Fruit firmness measurements in red raspberry. HortScience 15:38-39.

Daubeny, H.A. 1971. Self-fertility in red raspberry cultivars and selections. J. Amer. Soc. Hort. Sci. 96:588-591.

Daubeny, H.A. and C. Kempler. 1995. 'Qualicum' red raspberry. HortScience 30:1470-1472.

Daubeny, H.A. and H.S. Pepin. 1974. Variations among red raspberry cultivars and selections in susceptibility to the fruit rot causal organisms, Botrytis cinerea and Rhizopus spp. Can. J. Plant Sci. 54:511-516.

Daubeny, H.A., R. Stace-Smith, and J.A. Freeman. 1978. The occurrence and some effects of raspberry bushy dwarf virus in red raspberry. J. Amer. Soc. Hort. Sci. 103:519-522.

Graham, J., K. Smith, M. Woodhead, and J. Russell. 2002. Development and use of simple sequence repeat SSR markers in Rubus species. Molecular Ecology Notes 2:250-252.

Kempler, C. and H.A. Daubeny. 2000. 'Malahat' red raspberry. HortScience 35:783-785.

Kurppa, A. and R.R. Martin. 1986. Use of doublestranded RNA for identification of virus diseases of Rubus species. Acta Hort. 186:51-62.

Levesque, C.A. and H.A. Daubeny. 1999. Variation in reaction to Phytophthora fragariae var. rubi in raspberry genotypes. Acta Hort. 505:231-235.

Martin, R.R. 1998. Raspberry viruses in Oregon, Washington, and British Columbia. Acta Hort. 471:71-74.

Table 4. Morphological characteristics of plant parts of 'Cowichan' and other Pacific Northwest red raspberry cultivars measured in 2005 on dormant canes from the site planted in 2000.

\begin{tabular}{|c|c|c|c|c|c|c|c|c|}
\hline Cultivar & $\begin{array}{c}\text { Floricane } \\
\text { diam } \\
\text { at } 30-\mathrm{cm} \text { ht } \\
(\mathrm{mm})\end{array}$ & $\begin{array}{l}\text { No. of } \\
\text { buds/ } \\
\text { cane }\end{array}$ & $\begin{array}{l}\text { No. of } \\
\text { fruiting } \\
\text { laterals/ } \\
\text { cane }\end{array}$ & $\begin{array}{l}\text { Lateral } \\
\text { dry wt } \\
\text { (g) }\end{array}$ & $\begin{array}{l}\text { Lateral } \\
\text { length } \\
(\mathrm{cm})\end{array}$ & $\begin{array}{c}\text { Budbreak } \\
(\%)\end{array}$ & $\begin{array}{c}\text { Primocane } \\
\text { dry wt/ } \\
\text { plant } \\
\text { (g) }\end{array}$ & $\begin{array}{c}\text { No. of } \\
\text { primocanes/ } \\
\text { plant }\end{array}$ \\
\hline Cowichan & 11 & 23 & 15 & 0.40 & 45 & 65 & 103 & 17 \\
\hline Qualicum & 10 & 26 & 14 & 0.38 & 42 & 55 & 49 & 10 \\
\hline Meeker & 9 & 27 & 15 & 0.54 & 44 & 55 & 89 & 14 \\
\hline Malahat & 9 & 28 & 12 & 0.34 & 30 & 42 & 111 & 18 \\
\hline Tulameen & 8 & 25 & 13 & 0.42 & 38 & 52 & 97 & 11 \\
\hline $\mathrm{LSD}^{\mathrm{z}}$ & 2 & 6 & 3 & 0.14 & 13 & 9 & 57 & 8 \\
\hline
\end{tabular}

${ }^{\mathrm{z}}$ Mean separation with least significant difference (LSD), $P=0.05$. 